\title{
EFFECT OF LEMON (CITRUS LIMON L.) ADDITION TO Pluchea indica Less BEVERAGE
}

\author{
P.S. Widyawati ${ }^{\bowtie}$, T.I.P. Suseno ${ }^{1}$, A.R. Utomo ${ }^{1}$, T.L. Willianto ${ }^{1}$, C. Yohanita $^{1}$ and T.A. $^{\text {T. }}$ \\ Wulandari ${ }^{1}$ \\ ${ }^{I}$ Department of Food Technology, Agricultural Technology Faculty, Widya Mandala Catholic University \\ Surabaya, East Java, Indonesia. \\ 凶wiwiedt@gmail.com; paini@ukwms.ac.id \\ https://doi.org/10.34302/crpjfst/2020.12.4.13 \\ Article history: \\ Received: \\ 21 March 2018 \\ Accepted: \\ 17 September 2020 \\ Keywords: \\ Pluchea indica Less, \\ Lemon juice, \\ Physicochemical, sensory, \\ Antioxidant and antidiabetic \\ properties.

\begin{abstract}
This study was conducted with the aim of estimating quantitative changes in physicochemical, and sensory properties, antioxidant and antidiabetic activities of Pluchea indica Less leaves beverage caused lemon juice addition. The previous research has showed that the drink of $2 \mathrm{~g}$ dried pluchea leaves powder has the highest sensory acceptance but it owns the lowest antioxidant activity. The phytochemical contents of lemon juice expected can increase the antioxidant activity of this beverage. The lemon juice at various concentrations $(0,1,2,3,4$, and $5 \% \mathrm{v} / \mathrm{v})$ was added in 100 $\mathrm{mL}$ of hot water $\left(\sim 95^{\circ} \mathrm{C}\right)$ extract for $5 \mathrm{~min}$ from dried Pluchea leaves powder in tea bag packaging. Parameters were tested physicochemical properties including turbidity, color, $\mathrm{pH}$, total acid; antioxidant and antidiabetic activities and sensory properties comprising taste, color, and aroma. The results showed that the addition of lemon juice at various concentration can increased turbidity, lightness, total acid, total phenolic content, total ascorbic acid, total flavonoid, antioxidant activity and antidiabetic activity and decreased $\mathrm{pH}$ of beverages. The existence of phytochemical compounds of beverage from lemon juice and pluchea leaves gave to contribute the interaction of their constituents that were influenced to physicochemical and sensory properties, antioxidant and antidiabetic activities. This case study, it estimated that the organic acid content, especially citric acid and ascorbic acid from lemon juice could hydrolyze of glycoside bond or ester bond of phytochemical compounds in hot water extract of Pluchea leaves that could increase antioxidant and antidiabetic activities.
\end{abstract}

\section{Introduction}

Functional beverage usually is consumed by people to preserve body health. Pluchea indica Less, a herb plant including Asteraceae family, has been used as herbal drink (Srisook et al., 2012; Widyawati et al., 2016) because pluchea leaves water extract contains phytochemical compounds, such as flavonoid, saponin, tannin, phenolic, alkaloid, and cardiac glycoside (Widyawati et al., 2016; Widyawati et al., 2014). Andarwulan et al. (2010) also reported that pluchea leaves contain quercetin $5.21 \mathrm{mg} / 100 \mathrm{~g}$ fresh weight and kaempherol $0.283 \mathrm{mg} / 100 \mathrm{~g}$ fresh weight.

The previous research founded that $2 \mathrm{~g}$ dried pluchea leaves powder in tea bag packaging brewed in $100 \mathrm{~mL}$ of hot water $\left(\sim 95^{\circ} \mathrm{C}\right)$ results the highest sensory acceptance but the lowest antioxidant activity. The lemon addition of pluchea beverage was hoped to increase antioxidant activity. Zhou et al. (2015) reported that there are more than 170 antioxidants in citrus fruits, such as vitamins, mineral elements, phenolic compounds, terpenoids, and pectin. The vitamin $\mathrm{C}$ is a major vitamin in citrus fruit 
that is a water-solubility substance. It can scavenge free radical, such as reactive oxygen species (ROS) and give off semi dehydroascorbic acid, clearing ${ }^{1} \mathrm{O}_{2}$ and reducing sulfur radicals. Se content of citrus fruit $(0.5$ $\mu \mathrm{g} / 100 \mathrm{~g})$ can be acted as antioxidant to destroy free radical cytoplasm and protect the tissues against oxidative damage. Phenolic compounds in citrus fruit, such as flavonoid, phenolic acid and coumarin are potential as antioxidant. Vandercook \& Stephenson (1966) explained that phenolic compounds in lemon usually are formed aglycones and glycosides structures. There are some varieties of the coumarin compounds in lemon juice, such as 5geranoxypsoralen, 8-geranoxypsoralen, 5geranoxy-7-methoxycoumarin, 5,7-dimethoxy coumarin, oxpeucedanin hydrate, and byakangelicin. Tyagi et al. (2005) said that coumarins possess strong antioxidant activities because of their phenolic hydoxyl groups. Zhou et al. (2015) described that there are flavonoid compounds in citrus fruit having antioxidant activity, i.e. naringin, hesperidin and naringenin. The major flavanones compounds in lemon juice are hesperidin. This compound can scavenge DPPH free radical, inhibit $\mathrm{Cu}^{2+}$-induced oxidation of low density lipoprotein (LDL) in vitro, promote pancreatic $\beta$ cells regeneration, and prevent the oxidative stress on the embryos of diabetic pregnant rats. The content of hisperidin in lemon is $22 \mathrm{mg} / 100 \mathrm{~g}$.

There are free phenolic compounds from pluchea leaves and lemon juice in beverage caused interaction of hydroxyl groups so that influences the physicochemical and sensory beverage. The distance among the hydroxyl groups of phenolic compounds in beverage determines hydrogen bond formation so that establishes phenolic compounds solubility. Citric acid is major organic acid (1.44 g/oz) and ascorbic acid (Penniston et al. 2009) in lemon juice can hydrolyze glycoside bond or ester bond of phenolic compounds so that total aglycones components and solubility of them increase. Thereby the study was conducted to predict the effect of lemon juice addition to quantitative changes in physicochemical, and sensory properties, antioxidant and antidiabetic activities of Pluchea indica Less leaves beverage.

\section{Materials and methods \\ 2.1. Chemicals}

Reagents used to analyze were analytical grade, including sodium acetate, chloroform, sulphuric acid, mercury chloride, potassium iodide, sodium hydroxide, folin ciocalteus phenol, cuppric sulphate, sodium nitrite, sodium dihydrogen phosphate, disodium hydrogen phosphate, methanol, eter, ethanol, ammonia solution, potassium ferric cyanide, trichloro acetic acid, acetic acid glacial, iodine, hydrochloride acid, n-amyl alcohol, magnesium powder, and ferric chloride were purchased by Merck Company (Darmstadt, Germany). Potassium sodium tartrate tetrahydrate, gallic acid, sodium carbonate, $(+)$-catechin, aluminium chloride, 2,2-diphenyl-1-picrylhydrazyl, alpha amylase enzyme, alpha glycosidase enzyme, amylum, and p-nitrophenyl- $\alpha$-Dglucopyranoside were purchased from SigmaAldrich Company Ltd. (Gillingham, UK). Distillated water was supplied by PT Aqua Surabaya, Indonesia.

\subsection{Materials}

\subsubsection{Plant Samples}

Pluchea leaves were collected from a pluchea garden in manggrove area, Wonorejo, Rungkut, Surabaya, East Java, Indonesia. The plant was authenticated in the Herbarium of Biology and Food Industry Microbiology Laboratory at the Department of Food Technology, Agricultural Technology Faculty, the Widya Mandala Catholic University of Surabaya with voucher specimen no FTPUKWMS-0001 for future reference (Widyawati et al. 2017). These leaves were sorted and graded based on age level and selected to get whole leaves. And then this leaves were used as samples. Lemon fruit were purchased from Hokky Supermarket in Surabaya, East Java, Indonesia with skin characteristic such as bright yellow color, smooth, and hard texture. Mineral water from commercial product was bought 
from Bilka Supermarket in Surabaya, East Java, Indonesia. Tea bag was purchased from CV Peri Akas in Kwarasan, DI Yogjakarta, Indonesia.

\subsubsection{Sampling}

Pluchea leaves were harvested from 1-6 age level (Widyawati et al. 2014). The leaves were dried at room temperature around 7 days and ground to a fine powder (40 mesh) after they were washed and drained. The moisture content was determined to be $14.96 \%(\mathrm{db})$. And then dried leaves powder was mixed before used.

\subsubsection{Preparation of Pluchea Lemon Juice} Beverage

Dried pluchea leaves powder was weighed $2 \mathrm{~g}$ in tea bag. And then it was extracted by 100 $\mathrm{mL}$ hot water $\left(\sim 95^{\circ} \mathrm{C}\right)$ and mixed for $5 \mathrm{~min}$. Lemon juice at various concentrations $(0,1,2$, 3,4 , and $5 \% \mathrm{v} / \mathrm{v}$ ) was added after sample temperature similar to ambient temperature around $15 \mathrm{~min}$. Then this beverage was mixed and analyzed further.

\subsubsection{Physicochemical Analysis}

Turbidity of samples was analyzed based on Giwa et al. (2012). Turbidity is turbid condition or transparency reduction of liquid because there is a suspended particle in liquid. The quantity of beam absorbed is principled of turbidity measurement (Turbidity meter 966 IR, Orbeco Hellige, USA) (Omar et al. 2009). The higher of NTU (Nephelometric Turbidity Unit) is the bigger of turbid. The potential hydrogen is analyzed by AOAC (2005) method ( $\mathrm{pH}$ meter Schott Lab 850, Germany). Principle analysis of $\mathrm{pH}$ is measurement of free hydrogen ion stated as acidity or alkalinity of samples. Total acid is measured by volumetric analysis (AOAC 2005). Principle analysis of total acid is neutralization reaction between hydrogen ion of acid and hydroxyl ion of base resulted water molecule. Sodium hydroxide $0.01 \mathrm{~N}$ called the titrant or titrator was prepared as a standard solution and phenolphthalein $1 \%(\mathrm{w} / \mathrm{v})$ was used as a indicator. Color of samples was analyzed by Color Reader (Color Reader CR 20, Minolta, Japan) with using hunter system to determine $\mathrm{L}^{*}, \mathrm{a}^{*}$, and $\mathrm{b}^{*}$ values (McDaugall 2005). $\mathrm{L}^{*}$ value is lightness having value between 0 (black) and 100 (white). a* value is redness showing mixed chromatic color between red $\left(+a^{*}\right)$ and green $\left(-a^{*}\right)$. $b^{*}$ value is yellowness having value between yellow $\left(+\mathrm{b}^{*}\right)$ and blue ($\left.b^{*}\right)$.

\subsubsection{Sensory Evaluation}

Sensory evaluation was analyzed sensory based on hedonic preference test including aroma, taste, and color. Panelist number used was 80 . Sensory assay used scoring test with 17 range. 1 score stated very dislike of samples and 7 showed very like of samples (Lawless 1999).

\subsubsection{Phytochemical Composition}

Phytochemical compounds identified including alkaloid, flavonoid, phenolic, triterpenoid, sterol, saponin, tannin, and cardiac glycoside (fehling test) were based on Harbone method (Harborne 1996). Identification of phytochemical compounds was showed with qualitative color of solution with color reader assay (Color Reader CR 20, Minolta, Japan) to determine color intensity.

\subsubsection{Total Phenol Content Analysis}

Total phenol content (TPC) was analyzed with folin ciocalteu's phenol reagent. The principle analysis is redox reaction between antioxidant compounds having aromatic ring and phosphomolybdate compound in folin ciocalteu's phenol reagent. The samples of beverage $(100 \mathrm{~mL})$ were added to $1 \mathrm{~mL}$ folin ciocalteu reagent $10 \%$. After $5 \mathrm{~min}, 1 \mathrm{~mL}$ of $7.5 \% \quad \mathrm{Na}_{2} \mathrm{CO}_{3}$ was added, and then the mixture of samples was diluted by distillated water until $10 \mathrm{~mL}$ volume which was then left to stand for $30 \mathrm{~min}$. Absorbance was read at $750 \mathrm{~nm}$ using a spectrophotometer (Spectrophotometer UVVis-1800, Shimadzu, Japan) and compared to gallic acid calibration curves. The content of total phenolics was expressed as mg gallic acid equivalent/L samples (mg GAE/L samples) (Singleton 1999).

\subsubsection{Total Flavonoid Content Analysis}

Total flavonoid content (TFC) was determined based on a stable acid complex compound formation of reaction between $\mathrm{AlCl}_{3}$ and oxo group at $\mathrm{C}_{4}$ ring and hydroxyl group at $\mathrm{C}_{3}$ or $\mathrm{C}_{5}$ ring of flavones and flavonol. Briefly, $200 \mu \mathrm{L}$ of samples was added with $0.15 \mathrm{~mL}$ of 
$5 \% \mathrm{NaNO}_{2}$. After $5 \mathrm{~min}, 0.3 \mathrm{~mL}$ of $10 \% \mathrm{AlCl}_{3}$ was added. After another $5 \mathrm{~min}, 2 \mathrm{~mL}$ of $1 \mathrm{~mol} / \mathrm{L}$ $\mathrm{NaOH}$ was added to the mixture. And then the samples were diluted by distilated water until 10 $\mathrm{mL}$ volume. Immediately, the absorbance of the mixture was determined by a spectrophotometer (Spectrophotometer UV-Vis-1800, Shimadzu, Japan) at $510 \mathrm{~nm}$ versus prepared water blank. Total flavonoids of samples were expressed as $\mathrm{mg}$ catechin equivalent/L samples $(\mathrm{mg} \mathrm{CE} / \mathrm{L}$ samples) (Al-Temimi \& Choudhary 2013).

\subsubsection{Ascorbic Acid Content Analysis}

Ascorbic acid is a phytochemical compound that is acted as antioxidant (Taylor 1993) because this compound can donor electron so that it can prevent oxidation (Padayatty 2003). $250 \mu \mathrm{L}$ of samples was diluted by distillated water until $10 \mathrm{~mL}$ volume and then the samples were mixed. Ascorbic acid content was analyzed by a spectrophotometer (Spectrophotometer UV Vis-1800, Shimadzu, Japan) at $\lambda 265 \mathrm{~nm}$ based on Hassan et al. (1999) method.

\subsubsection{DPPH Free Radical Scavenging Activity Analysis}

The principle analysis is electron or hydrogen donating of antioxidant compounds to DPPH free radical colored purple to form DPPH-H non radical colored yellow. In this assay, $15 \mu \mathrm{L}$ of samples with different concentrations of lemon juice addition was added with $1.5 \mathrm{~mL}$ of $60 \mu \mathrm{M}$ methanolic-DPPH and added with methanol 1.5 $\mathrm{mL}$. The mixture was shaken vigorously using vortex and left to stand for $30 \mathrm{~min}$ at room temperature in a dark room, and then samples were measured by a spectrophotometer (Spectrophotometer UV-Vis-1800, Shimadzu, Japan) at $\lambda 517 \mathrm{~nm}$ with gallic acid compound as standard (Brand-Williams et al. 1995). The radical scavenging percentage using the following equation: Percentage (\%) of DPPH free radical scavenging $=$

$$
\frac{(\mathrm{Ab}-\mathrm{AS})}{(\mathrm{Ab})} \times 100 \%
$$

Where,

$\mathrm{Ab}$ that absorbance of the blank solution (DPPH-methanolic solution), AS that absorbance of samples.

\subsubsection{Iron Reducing Power Analysis}

This analysis is used to determine of the antioxidant capacity to reduce $\mathrm{Fe}^{3+}$ to $\mathrm{Fe}^{2+}$ (Chanda \& Dave 2009). The pluchea-lemon beverages $(50 \mu \mathrm{L})$ were mixed with phosphate buffer (2.5 mL, 0.2 M, pH 6.6) and potassium ferric cyanide $\left[\mathrm{K}_{3} \mathrm{Fe}(\mathrm{CN})_{6}\right](2.5 \mathrm{~mL}, 1 \%)$. The mixture was incubated at $50^{\circ} \mathrm{C}$ for $20 \mathrm{~min}$. A portion $2.5 \mathrm{~mL}$ of trichloro acetic acid (10\%) was added to the mixture, which was then centrifuged at $1000 \mathrm{rpm}$ for $10 \mathrm{~min}$. The upper layer of $2.5 \mathrm{~mL}$ solution was mixed with $2.5 \mathrm{~mL}$ distilled water and $0.5 \mathrm{~mL} \mathrm{FeCl}_{3} 0.1 \%$. The complex compound from ferri ferro cyanide colored Berlin blue was determined by a spectrophotometer (Spectrophotometer UVVis-1800, Shimadzu, Japan) at $\lambda 700 \mathrm{~nm}$ with gallic acid compound as standard (Al-Temimi \& Choudhary 2009).

\subsubsection{In Vitro Inhibitory Alpha Amylase Assay}

The analysis of in vitro inhibition alpha amylase was done by modified Odhav et al. (2010) method. All of pluchea-lemon beverages with various concentrations of lemon juice were taken $500 \mu \mathrm{L}$ and added with $500 \mu \mathrm{L}$ of amylum $1 \%$ (dissolving $1 \mathrm{~g}$ of amylum in $100 \mathrm{~mL}$ of distilled water with boiling and stirring for 15 $\mathrm{min}$ ). And then $500 \mu \mathrm{L}$ of sodium acetate buffer at pH 5 was added and mixed. $250 \mu \mathrm{L}$ of samples was mixed by $250 \mu \mathrm{L}$ alpha amylase enzyme solution $(0.1 \mathrm{~g}$ of $\alpha$-amylase $12.5 \mathrm{unit} / \mathrm{mL}$ in 50 $\mathrm{mL}$ of $0.2 \mathrm{M}$ sodium acetate at $\mathrm{pH} 5$. Furthermore, the mixture was added by $2 \mathrm{~mL}$ sodium hydroxide solution $1 \mathrm{M}$ and incubated at $37^{\circ} \mathrm{C}$ for $10 \mathrm{~min}$. The absorbance was measured at $540 \mathrm{~nm}$ by a spectrophotometer (Spectrophotometer UV-Vis-1800, Shimadzu, Japan). Lemon juice addition at different concentrations $(0,1,2,3,4$, and $5 \mathrm{mg} / \mathrm{mL})$ was performed in four replicates. Individual blank was performed by replacing enzyme with buffer. Control was performed by replacing sample with solvent. The inhibition percentage of $\alpha$ amylase was assessed by the following formula:

$$
\frac{(\mathrm{ACb}-\mathrm{ACa})-(\mathrm{AS}-\mathrm{Ab})}{(\mathrm{ACb}-\mathrm{ACa})} \times 100 \%
$$


Where,

$\mathrm{ACb}$ that absorbance of $100 \%$ enzyme activity (only solvent with enzyme), $\mathrm{ACa}$ that absorbance of $0 \%$ enzyme activity (only solvent without enzyme), As that absorbance of test sample with enzyme, $\mathrm{Ab}$ that absorbance of test sample without enzyme.

\subsubsection{In Vitro Inhibitory Alpha Glycosidase Assay}

The alpha glycosidase inhibitor assay was done by Mayur et al. (2010) with slight modification. $50 \mu \mathrm{L}$ of samples was added with $50 \mu \mathrm{L} 2 \mathrm{mM}$ P-nitrophenyl- $\alpha$-D-glucopiranoside (PNP) $(0.0150 \mathrm{~g}$ in $100 \mathrm{~mL}$ of $0.2 \mathrm{M}$ sodium phosphate buffer $(\mathrm{pH} 7)$ used as a substrate to the mixture of $50 \mu \mathrm{L}$ of $\alpha$-glucosidase $(0.0833$ unit $/ \mathrm{mL}$ ). The reaction was conducted at $37^{\circ} \mathrm{C}$ for $15 \mathrm{~min}$ and stopped by the addition of 1000 $\mu \mathrm{L}$ of $0.2 \mathrm{M} \mathrm{Na}_{2} \mathrm{CO}_{3}$. $\alpha$-Glucosidase activity was assessed by measuring the release of $p$ nitrophenol from $\mathrm{pNPG}$ at $405 \mathrm{~nm}$. Lemon juice addition at different concentrations $(0,1,2,3,4$, and $5 \mathrm{mg} / \mathrm{mL}$ ) was performed in four replicates. Individual blank was performed by replacing enzyme with buffer. Control was performed by replacing sample with solvent. The inhibition percentage of $\alpha$-glycosidase was assessed by the following formula:

$$
\frac{(\mathrm{ACb}-\mathrm{ACa})-(\mathrm{AS}-\mathrm{Ab})}{(\mathrm{ACb}-\mathrm{ACa})} \times 100 \%
$$

Where,

$\mathrm{ACb}$ that absorbance of $100 \%$ enzyme activity (only solvent with enzyme), $\mathrm{ACa}$ that absorbance of $0 \%$ enzyme activity (only solvent without enzyme), As that absorbance of test sample with enzyme, $\mathrm{Ab}$ that absorbance of test sample without enzyme.

\subsubsection{4 .Statistical Analysis}

The results were expressed as mean \pm standard deviation of four replicates. ANOVA was used to execute the analysis of significant difference $(\alpha=5 \%)$ with SAS (SAS/STAT version 17.0, SAS Institute Inc., Cary, NC, USA) if that test is significantly different followed by Duncan's Multiple Range Test at $\alpha$ $=5 \%$ ).

\section{Results and discussion}

\subsection{Physicochemical properties}

The change of physicochemical properties from pluchea leaves beverage with lemon juice addition at various concentrations was showed at Figure 1 and 2. The appearance of pluchealemon beverage after 15 min was extracted by hot water at $\sim 95^{\circ} \mathrm{C}$ for $5 \mathrm{~min}$ was showed at Figure 3.

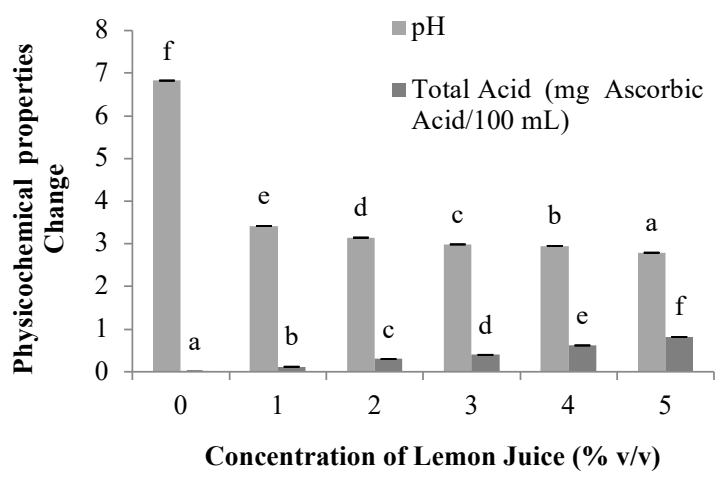

Figure 1. The effect of lemon juice addition at various concentrations of $\mathrm{pH}$ and total acid changes from pluchea-lemon beverage

Lemon juice addition caused significant different of increased turbidity, total acid and lightness but $\mathrm{pH}$ value of beverages showed significantly decreased $(\mathrm{p}<0.05)$.

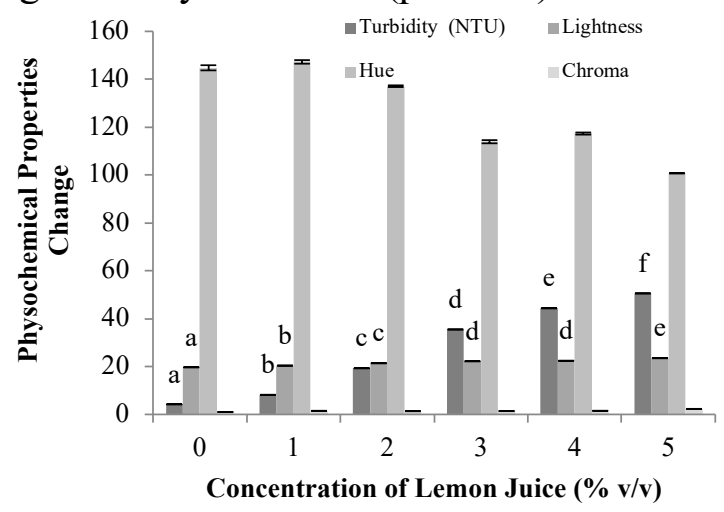

Figure 2. The effect of lemon juice addition at various concentrations of turbidity, hue, lightness and chroma values from pluchealemon beverage 


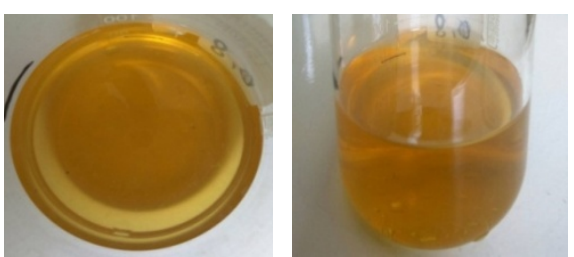

Figure 3. The appearance of pluchea-lemon beverage after 15 min was extracted by hot water at $\sim 95^{\circ} \mathrm{C}$ for $5 \mathrm{~min}$

The possible of explanation for the turbidity change in pluchea leaves beverage was caused by total soluble solid (TSS) increasing. Lemon (Citrus limon cv Eureka) has 8.97 \% TSS (AlJuhaimi \& Ghafoor 2013), it is contributed by phytochemical compounds, such as mineral, vitamin, carbohydrate, protein, copper, calcium, vitamin B9, B1, B3, B6, phenolic (FernandezLopez et al. 2005; Jayaprakasha et al. 2008), flavonoids, coumarins, limonoids, carotenoids, pectins and other components (Zhou 2015). The solubility of phytochemical constituents in beverages determined turbidity value. Generally, phenolic compounds in lemon juice have free and bond structures (Vandercook \& Stephenson 1966), it is similar as the phenolic compounds of water extract of pluchea leaves powder so that the addition of lemon juice in this beverage caused interaction of hydroxyl groups among phenolic compounds to form insoluble macromolecules. Siebert et al. (1996) said that tannin acid, catechin and gelatin can cause haze increasing in wine, beer and fruit juices. The precipitating ability of polyphenols increases as the number of o-diphenol groups in the molecule increases. Tannic acid or proanthocyanidin dimers or trimers is more effective to make haze in beverages than catechin having one odiphenol group and one m-diphenol group.

The some studies have suggested that lemon contains potasium, phosphor, magnesium, and E, kolin, ascorbic acid, flavonoid, B2, and B5 (Molina et al. 2010), vitamin A and the phytochemical compounds. Pluchea leaves beverage has brown yellowish color, because pluchea leaves contain tannin (Widyawati et al. 2016). Lemon juice addition of samples can increase lightness value of this beverage. The lightness change of samples was related with pigment color from lemon fruit, chlorophyll and its derivate give green to yellow color. However the beverage lightness value increasing didn't contribute to hue and chroma values change. It means the interaction of molecule structures in phenolic compounds from pluchea leaves and lemon is not influenced beverage color. Although Tapas et al. (2008) said that the different molecule structures of phenolic compounds are responsible to color of beverages.

$\mathrm{pH}$ and total acidity of lemon fruit juice are 2.81 and $6.49 \pm 0.01 \mathrm{~g} / \mathrm{L}$, respectively (AlMusharfi et al. 2015). The major organic acids in lemon are citric acid $(1.44 \mathrm{~g} / \mathrm{oz})$ and ascorbic acid (Penniston et al. 2009), and then the dominan organic compounds in pluchea leaves is chlorogenic acid and caffeic acid (Apriady 2010). The soluble organic compounds in pluchea-lemon beverage determined total acid and $\mathrm{pH}$, were depended on the added lemon juice concentration, the maturity of lemon fruit determines total soluble solid and acid content.

\subsection{Sensory properties}

Sensory properties of pluchea-lemon beverage were showed at Figure 4. From the evaluation of panelist based on hedonic preference test was indicated significant different $(\mathrm{p}<0.05)$ in the color, taste and aroma of beverages. Data showed that aroma acceptance increased corresponding to the progress of lemon juice concentration. It must be noted that as essential oil in pluchea leaves and lemon fruit give contribution to the aroma of the drink. Traithip (2005) informed that pluchea leaves are comprised volatile compounds, such as boehmeryl acetate, HOP-17 (21)-ene 3 $\beta$ acetate, linaloyl glucoside, linaloyl apiocyl glucoside, plucheoside C, cuauhtermone, 3-(2'3'-diacetoxy-2'methyl-butyril), plucheol A, plucheol B, plucheoside A, plucheoside B, plucheoside E, pterocarptriol, sequisterpene, monoterpene, and triterpene. Widyawati et al. (2013) also found that essential oil in pluchea leaves is composed alcohol (6.16\%), aldehide $(1.79 \%)$, aliphatic unsaturated hydrocarbon 
$(1.35 \%)$, ester $(0.08 \%)$, keton $(3.49 \%)$, eter and sulphoxide $(0.06 \%)$, aromatic hydrocarbon $(2,05 \%)$, heterocyclic hydrocarbon $(0.05 \%)$. Hui (2010) said that monoterpene (C10) and sequisterpene (C15) of lemon fruit give aroma specific. Volatile compounds from pluchea leaves and lemon fruit contributed of the drink aroma.

The taste and color acceptances of samples were significant increased at lemon juice concentration addition until $3 \%$. The declining acceptance of taste was caused by sour taste contributed by ascorbic acid and citric acid from lemon fruit, whereas the color acceptance was influenced by yellow color intensity increasing from samples because of soluble carotenoid pigment from lemon juice. Jokic et al. (2014) informed

Table 1. Phytochemical analysis of pluchea leaves beverages with lemon juice addition at various concentrations

\begin{tabular}{|c|c|c|c|c|c|c|c|}
\hline \multirow{2}{*}{\multicolumn{2}{|c|}{$\begin{array}{c}\text { Phytochemical } \\
\text { Compounds }\end{array}$}} & \multicolumn{6}{|c|}{ Concentration of Lemon Juice (\% v/v) } \\
\hline & & \multirow{2}{*}{$\begin{array}{c}0 \\
+1\end{array}$} & \multirow{2}{*}{$\frac{1}{+2}$} & \multirow{2}{*}{$\frac{2}{+2}$} & \multirow{2}{*}{$\begin{array}{c}3 \\
+3\end{array}$} & \multirow{2}{*}{$\begin{array}{c}4 \\
+4\end{array}$} & \multirow{2}{*}{$\begin{array}{c}5 \\
+5\end{array}$} \\
\hline \multirow{2}{*}{ Alkaloids } & Meyer & & & & & & \\
\hline & Wagner & +1 & +1 & +2 & +2 & +2 & +3 \\
\hline \multicolumn{2}{|c|}{ Flavonoids } & +2 & +2 & +2 & +3 & +3 & +3 \\
\hline \multicolumn{2}{|c|}{ Polyphenols } & +2 & +2 & +2 & +3 & +4 & +5 \\
\hline \multicolumn{2}{|c|}{ Tannins } & +2 & +2 & +3 & +4 & +4 & +4 \\
\hline \multicolumn{2}{|l|}{ Saponins } & +2 & +3 & +3 & +2 & +2 & +1 \\
\hline \multicolumn{2}{|c|}{ Cardiac Glycosides } & + & + & +2 & +4 & +4 & +5 \\
\hline \multicolumn{2}{|c|}{ Triterpenoids } & - & - & - & - & - & - \\
\hline \multicolumn{2}{|c|}{ Sterols } & - & - & - & - & - & - \\
\hline
\end{tabular}

Note : + Indicates : presence, - Indicates : absence

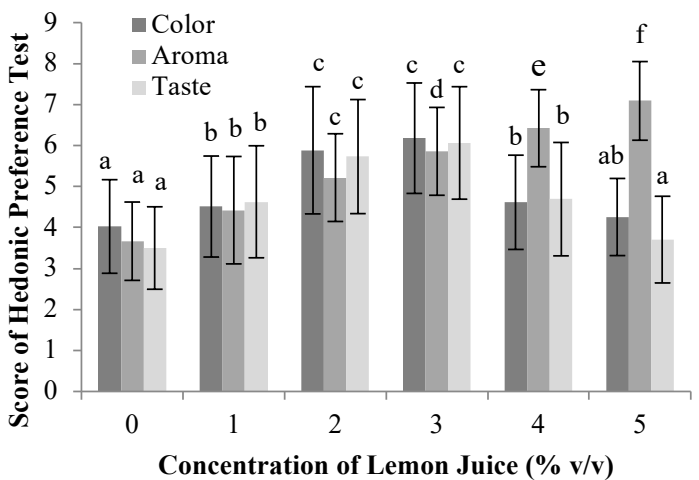

Figure 4. The effect of lemon juice addition at various concentrations of sensory properties from pluchea-lemon beverage

that phenolic compounds represent an important component of fruits and vegetables because they are significantly contributed to the taste, color and nutritional value of fruits and vegetables. Agbo et al. (2015) said that ascorbic acid is bioactive compounds in lemon fruit that is contributed to body health. The present of ascorbic acid in lemon fruit can influence sensory acceptance of panelist. Zhou et al. (2015) also described that vitamin $\mathrm{C}$ is soluble compounds in water contributed to taste of samples.

\subsection{Phytochemical composition}

Qualitative phytochemical analysis revealed the presence of tannins, flavonoids, polyphenols, alkaloids, saponins, and cardiac glycosides in pluchea-lemon beverage (Table 1). The lemon juice presence in this beverage increased detected phytochemical compounds quantity that was showed by color intensity of samples. It was proved that lemon fruit contains the phytochemical compounds mentioned. The phytochemical compound contents of the lemon juice are also observed by Mathew et al. (2012). 
Whereas saponin detection had the different pattern, it was caused that saponin was absent in lemon juice. However Okwu (2008) informed that Citrus limonum has saponin content around $0.42 \pm 0.01 \mathrm{mg} / 100 \mathrm{~g}$. The pattern change of saponin detection at phytochemical compounds identified was estimated by interaction among phytochemical compounds in pluchea leaves and lemon juice. The previous studies have informed that lemon fruit is composed with ascorbic acid, flavonoids, polyphenols, and pectins (Fernandez-Lopez et al. 2005; Jayaprakasha et al. 2008, Zhou et al. 2015), organic acids and essential oils (limonene, $\alpha$ terpinene, $\alpha$-pinene, $\beta$-pinene, citric acid, and caumarin (Molina et al. 2010), simple carbohydrate (glucose, fructose and sucrose) (Yekeler et al. 2013). Liu et al. (2004) said that saponins consist of a polycyclic aglycones attached to one or more sugar side chains. The aglycone part, which is also called sapogenin, is either steroid (C27) or a triterpene (C30). Saponin can be detected in samples based on the capability of saponin to make stable foam. The increasing of lemon juice concentration addition was estimated to cause glycoside bond of saponin hydrolyzed because of the interaction between organic acid compounds from lemon juice and glycoside bond from saponin. Whereas the lemon juice addition gave contribution of increasing from other phytochemical constituents

\subsection{Total phenolic content, total flavonoid content and total ascorbic acid}

The results of the qualitative phytochemical assay of the samples had the same pattern as the results of total phenolics (TPC), ascorbic acid (AAC) and total flavonoids (TFC) contents that were showed in Figure 5, 6 and 7.

It was observed that the lemon juice concentration increasing of the compared samples increased in the level of TPC, AAC, and TFC. Statistical analysis (Anova, $\mathrm{p}<0.5 \%$ ) showed that there were significant different in the level of TPC, AAC, and TFC. It means that the bioactive compounds of lemon juice gave contribution to the TPC, TFC and AAC increasing in samples. The TPC, TFC, and AAC of samples were ranged from $225.42 \pm 13.50$ to $398.85 \pm 13.09 \mathrm{mg}$ GAE/L, $150.01 \pm 3.87$ to $214.98 \pm 2.75 \mathrm{mg} \mathrm{CE} / \mathrm{L}$, and $18.40 \pm 0.49$ to $30.77 \pm 0.71 \mathrm{mg}$ AAE/L, respectively.

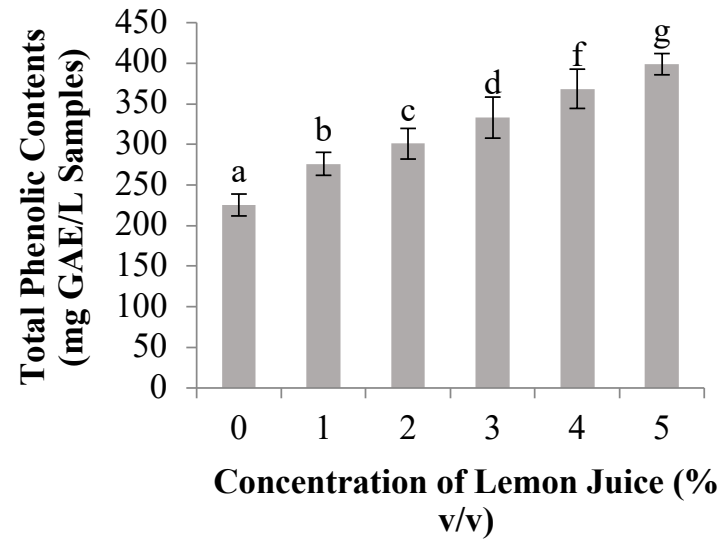

Figure 5. The effect of lemon juice addition at various concentrations of total phenols content

(TPC) from pluchea-lemon beverage

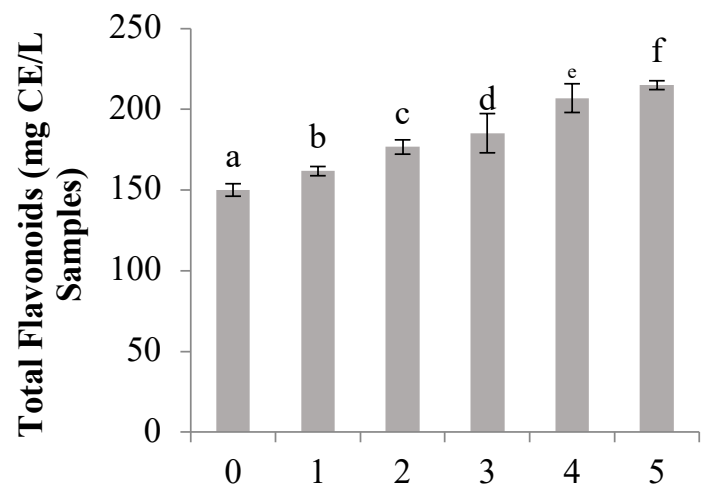

Concentration of Lemon Juice (\% $\mathbf{v} / \mathbf{v})$

Figure 6. The effect of lemon juice addition at various concentrations of total flavonoids contents (TFC) from pluchea-lemon beverage

Phenolic compounds, including tannins, flavonoid, phenolic acids, qoumarine, quinine and other compounds, are bioactive compounds that are rich found in fruit juices (Bansode \& Chavan 2012; Firdrianny et al. 2014; Lee et al. 2014). Zhou et al. (2015) also explained that citrus fruit phenolic compounds that have antioxidant activity such as flavonoids, phenolic acids and coumarins. The phenolic compounds are one of the most important groups of 
secondary metabolites present in plants that are characterized by the possession of at least one aromatic ring carrying one or more hydroxyl groups (Rebaya et al. 2014). Phenolic compounds in fruits and vegetables usually form free or bond structures (Lim \& Loh 2016).

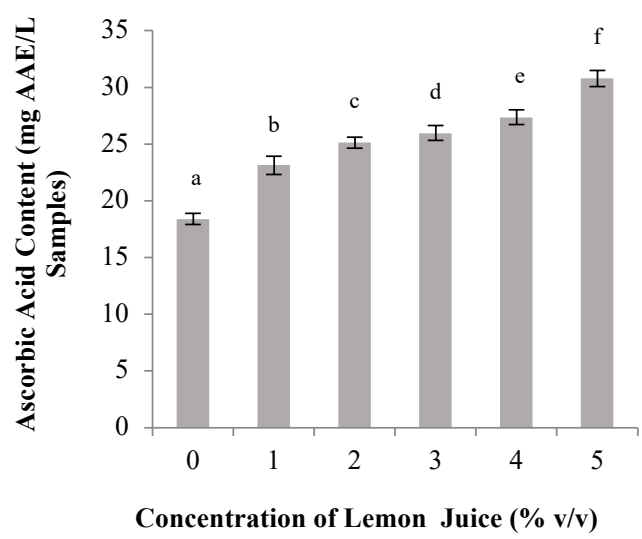

Figure 7. The effect of lemon juice addition at various concentrations of ascorbic acid content from pluchea-lemon beverage

Flavonoids are one class of phenolic compounds that are also known as vitamin $\mathrm{P}$. These metabolites are mostly used in plants to produce yellow and other pigments which play an important role in the colors of plants (Calabro et al. 2004). The TPC of lemon fruit juice is $0.569 \pm 0.031 \mathrm{mg} \mathrm{GAE} / \mathrm{mL}$ (Porras et al. 2015). Flavanone, flavone and flavonol are a flavonoid compound group in lemon fruit (Mouly et al. 1994). Major flavonoid in lemon is hesperidin, narirutin, naringin and eryocitrin (Schieber et al. 2001; Andarwulan et al. 2010; Zhou et al. 2015), quercetin, tangeritin, and rutin (Yekeler et al. 2013). Phenolic and flavonoid in pluchea are quercetin, kaempherol, myricetin, luteolin, apigenin (Apriady 2010), caffeic acid and chlorogenic acid (Hajimahmoodi et al. 2012), Most of the fresh juices contain varying amount of water soluble vitamin $\mathrm{C}$ (ascorbic acid) which is the main nutritional component of these juices. The ascorbic acid content of lemon fruit juice is $0.616 \pm 0.042 \mathrm{~g} / 100 \mathrm{~mL}$ (Porras et al. 2015).

\subsection{DPPH radical scavenging activity}

The antioxidant activity was evaluated by two different spectrophotometric methods including DPPH and FRAP. The results were showed at Figure 8 and 9. It was demonstrated that the antioxidant activities of pluchea drink showed an increasing trend from low concentration to high concentration of lemon juice addition.

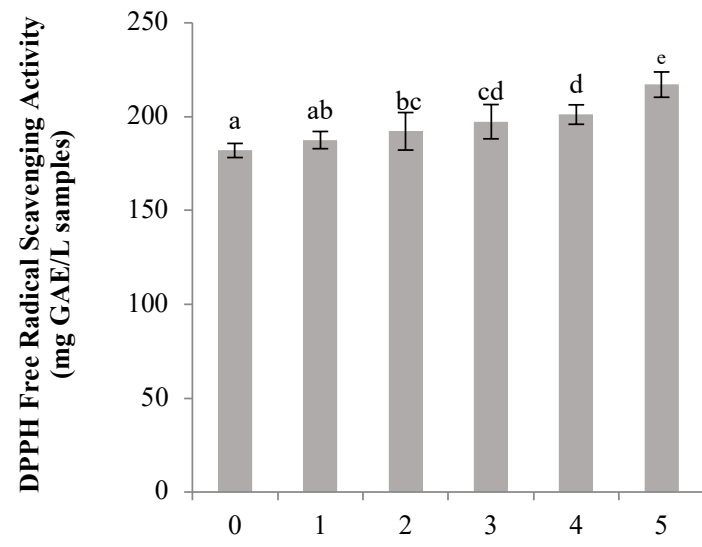

Concentration of Lemon Juice (\% v/v)

Figure 8. The effect of lemon juice addition at various concentrations of DPPH free radical scavenging activity from pluchea-lemon beverage

The scavenging activities for DPPH radical of samples was ranged from $181.98 \pm 3.76$ to 217.08 $\pm 6.74 \mathrm{mg}$ GAE/L samples. The lemon juice addition from 0 to $3 \%(\mathrm{v} / \mathrm{v})$ was obtained no significantly difference data, but this effect showed significant different at higher concentration addition $(\mathrm{p}<0.5 \%)$. This antioxidant capacity assay involves hydrogen atom transfer, DPPH free radical can receive hydrogen atom to form DPPH-H that is observed with color change from purple to yellow (Chlopicka et al. 2012). Zhou et al. (2015) informed that vitamin $\mathrm{C}, \mathrm{A}$, and $\mathrm{E}$, Se mineral, flavonoid, especially narigenin, naringin and hesperidin, phenolic acid, and coumarins, limonoids and pectins in citrus fruit are capable to scavenge free radical, such as reactive oxygen spesies (ROS) and peroxyl radical. 
In this case study, steric accessibility is a major determinant of the analytical reaction. The small molecules of bioactive compounds are easier to react with DPPH free radical than the big molecules, because the small molecules have good access to reach the radical site (Stankovic 2011). This antioxidant activity was correlated with TPC, TFC and AAC.

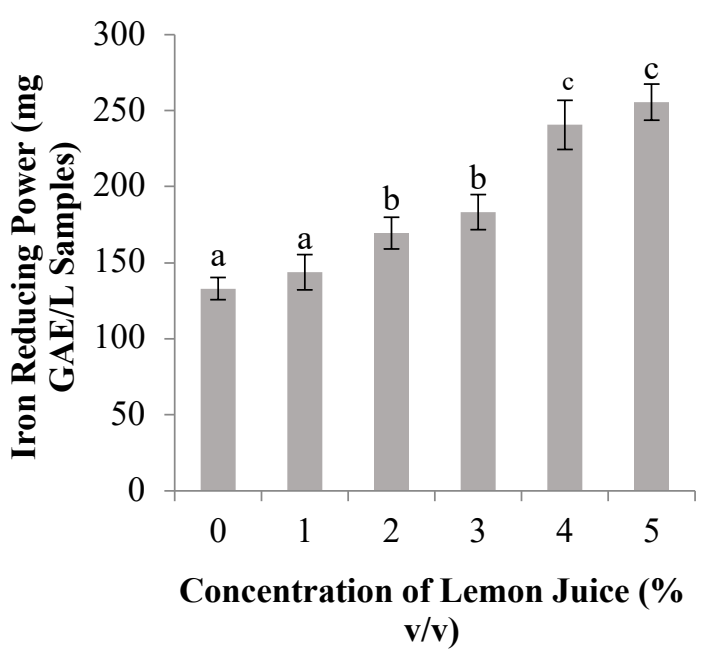

Figure 9. The effect of lemon juice addition at various concentrations of iron reducing power from pluchea-lemon beverage

\subsection{Ferric reducing antioxidant power}

The FRAP is antioxidant assay the corresponding concentrations of electron donating antioxidants and the compounds that act by radical quenching, i.e. thiol antioxidants (such as gluthathione) and carotenoids (Chlopicka et al. 2012). The ferric reducing power of samples was ranged from $133.03 \pm 7.30$ to $255.64 \pm 11.89 \mathrm{mg}$ GAE/L samples. The statistical data showed that the lemon juice addition at various concentrations of samples was significant different $(\mathrm{p}<0.5 \%)$.

The antioxidant activity was similar to trend observed in TPC, TFC, and AAC of samples. Agbo et al. (2015) said that the high phenolic content of samples indicates high antioxidant capacity because the phenolics react with active oxygen radicals such as hydroxyl radical, superoxide anon radical, and lipid peroxy radical. There are correlation among antioxidant activity, TPC, TFC, and AAC. Stankovic et al.
(2011) said that there are a high linear correlation between the values of phenol concentration and antioxidant activity. Phenol compounds can be acted as antioxidant due to their hydroxyl groups. Structure and substitution pattern of hydroxyl groups of phenolic compounds determine the antioxidant activity. Chlopicka et al. (2012) informed that among polyphenols the greatest antioxidant efficacies have antioxidant action, such as quercetin, tannic acid, caffeic acid, and gallic acid, while catechin and resveratrol have the lowest ones. The most effective antioxidants scavenging DPPH are gallic acid, tannin acid, ascorbic acid, and quercetin. Jablonska-Rys et al. (2009) explained that ascorbic acid is lower the antioxidant activity than the phenolic compounds. Therefore the antioxidant activity of pluchea drink was contributed by all of phytochemical compounds of lemon juice and pluchea leaves. The lemon juice addition containing phytochemical compounds caused the increasing of the antioxidant activity.

\subsection{In vitro inhibitory alpha amylase activity}

Previous research has showed that herbal plants can use to treat diabetes, as their principal bioactive components showed good antidiabetic and anti-oxidant properties (Keerthana et al. 2013). The effect of lemon juice addition at pluchea-lemon beverage was showed at Figure 10 . The alpha amylase inhibitory activity of samples was ranged from $55.30 \pm 2.90 \%$ to $84.85 \pm 2.47 \%$. The statistical data showed that the lemon juice addition at various concentrations of samples was significant different $(\mathrm{p}<0.5 \%)$. There was a positive relationship between antioxidant activity and alpha amylase inhibitory activity. The activity was influenced by TPC, TFC and AAC. The potency of samples inhibited alpha amylase activity is determined by the presence of potential inhibitors such as tannins, phenols, flavonoids, saponins, steroids, alkaloids, terpenoids (Myung-Hee et al. 2010; Nanumala et al. 2015). 


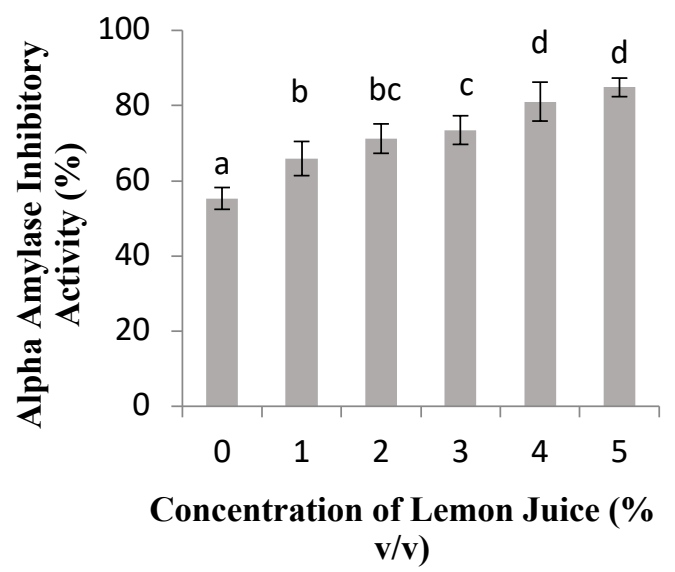

Figure 10. The effect of lemon juice addition at various concentrations of in vitro alpha amylase inhibitory activity from pluchea-lemon beverage

These alpha amylase inhibitors are also called as starch blockers since it prevents or slows the absorption of starch in to the body mainly by blocking the hydrolysis of 1,4-glycosidic linkages of starch and other oligosaccharides into maltose, maltriose and other simple sugars (Dineshkumar et al. 2010). The polyphenols and flavonoids have capability to bind with a active site of alpha amylase enzyme so that they can inhibit its activity. The ascorbic acid and citric acid existence in lemon juice are contributed as hydrolyzed agent to cleave a glycoside bond or ester bond in polyphenol compounds increasing a free polyphenols quantity. The free polyphenols have ability to bind with proteins (Fifa et al. 2013). Lim \& Loh (2016) underlined that the free soluble phenolics had slightly higher inhibitory $\alpha$-amylase activity than the bound phenolics. McCue et al. (2004) suggested that the effect of the free soluble phenolics to the five sets of disulphide bridges located on the outer surface of $\alpha$-amylase can reduce of these cysteine residues so that causes inhibition by modifying in the structure of the enzyme.

\subsection{In vitro inhibitory alpha glycosidase activity}

The $\alpha$-glucosidase enzyme is one of the key enzymes involved in dietary carbohydrate digestion in human. It hydrolyzes the carbohydrate, releasing glucose and cause the raised postprandial blood glucose level (Lee et al. 2014). In this study, the $\alpha$-glucosidase inhibitory activity of pluchea-lemon beverage at various concentration of lemon juice was showed at Figure 11.

The alpha glycosidase inhibitory activity of samples was ranged from $67.86 \pm 4.12 \%$ to $89.29 \pm 7.14 \%$. The statistical data showed that the lemon juice addition at $0-2 \% \quad(\mathrm{v} / \mathrm{v})$ concentrations of samples was significant different with 3-5 \% (v/v) concentrations $(\mathrm{p}<0.5 \%)$. However there was trend that lemon juice addition increased alpha glycosidase inhibitory activity. There was a positive relationship among TPC, TFC, AAC, antioxidant activity and alpha glycosidase inhibitory activity.

This antidiabetic activity is contributed by coumarin compounds, such as 5geranoxypsoralen, 8-geranoxypsoralen, 5geranoxy-7-methoxycoumarin, 5,7-dimethoxy coumarin, oxpeucedanin hydrate, and byakangelicin in lemon juice (Vandercook \& Stephenson 1966). Zhou et al. (2015) also explained that coumarins possess strong antioxidant activity because of their phenolic hydroxyl groups. The potency of alpha glycosidase inhibitory activity by caumarin compounds was ranged of $\mathrm{IC}_{50}$ values of 65.29$172.10 \mu \mathrm{M}$ (Ali et al. 2016).

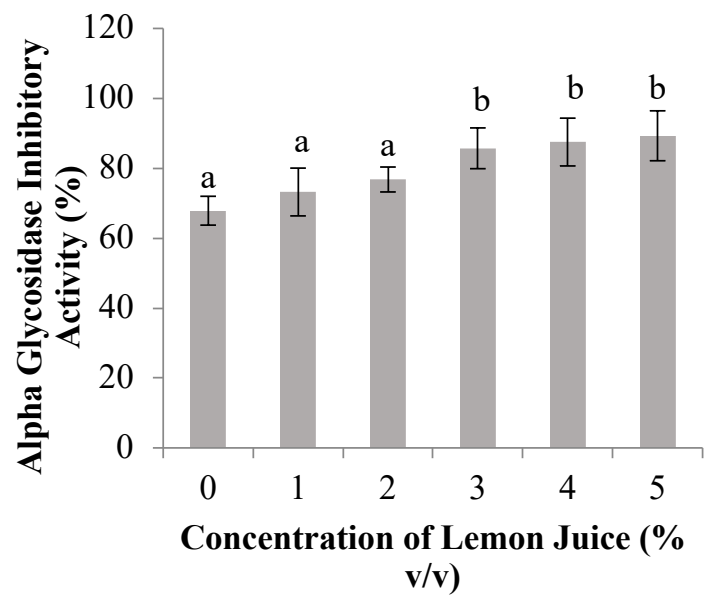

Figure 11. The effect of lemon juice addition at various concentrations of in vitro alpha glycosidase inhibitory activity from pluchealemon beverage 
Zhao et al. (2015) also clarified that the coumarin compounds are against $\alpha$-glucosidase activity with non competitive inhibition mode. The interaction between the coumarin compound and $\alpha$-glucosidase was a spontaneous process that was driven mainly by hydrophobic force. Astriningtyas et al. (2014) said that phytochemical compounds of pluchea leaves also are contributed to alpha glycosidase inhibitory activity, such as 3,5-di-Ocaffeoylquinic acid, 4,5-di-O-caffeoylquinic acid mehyl ester, 3,4,5-tri-O-caffeoylquinic acid methyl ester, 3,4,5-tri-O-caffeoylquinic acid and 1,3,4,5-tetra-O-caffeoylquinic acid.

Lim \& Loh (2016) explained that the bound phenolic compounds have slightly higher inhibitory effect in $\alpha$-glucosidase than the free phenolic compounds. The inhibitory mechanism of alpha glycosidase activity is none disulphide bridges especially not on the surface of the molecule (possible site for interaction with antioxidants) on the structure of Baker's yeast $\alpha$ glucosidase but the inhibition is attributed through other mechanism. This our study, the lemon juice addition could cause a glycoside bond or ester bond of phenolic compounds cleavage so that the total free phenolic compounds in beverage increased. Therefore it was predicted that the presence of some nonphenolic phytochemicals was acted as enzyme inhibitors, exhibiting an additive or synergistic effect with the present of phenolics in the sample.

\section{Conclusions}

The lemon juice addition at various concentrations was influenced physicochemical, antioxidant, antidiabetic and sensory properties of pluchea-lemon beverage. The type and number of phytochemical compounds and interaction among them were contributed to physicochemical, antioxidant, antidiabetic and sensory properties of samples.

\section{References}

Agbo, M.O., Uzor, P.F., Akazie-Nneji, U.N., Eze-Odurukwe, C.U., Ogbatue, U.B., Mbaoji, E.C. (2015). Antioxidant, total phenolic, flavonoid content of selected nigerian medicinal plants. Dhaka University Journal of Pharmaceutical Sciences, 14(1), 35-41.

Ali, M.Y., Jannat, S., Jung, H.A., Jeong Ho, Chung, H.Y., Choi, J.S. (2016). Coumarins from Angelica decursiva inhibit $\alpha$ glucosidase activity and protein tyrosine phosphatase 1B. Chemico- Biological Interactions, 252, 93-101.

Al-Juhaimi, F.Y., Ghafoor, K. (2013). Bioactive Compounds, Antioxidant and PhysicoChemical Properties of Juice From Lemon, Mandarin and Orange Fruits Cultivated in Saudi Arabia. Pakistan Journal of Botany, 45(4), 1193-1196.

Al-Musharfi, N.K., Al-Wahaibi, H.S., Khan, S.A. (2015). Comparison of ascorbic acid, total phenolic content, and antioxidant activity of fresh juice of six fruits in Oman. Journal of Food Process Technology, 6(Issue 11), 6-1.

Al-Temimi, A., Choudhary, R. (2013). Determination of antioxidant activity in different kinds of plants in vivo and in vitro by using diverse technical methods. Journal of Nutrition Food Sciences, 3,1-9.

Andarwulan, N., Batari, R., Sandrasari, D.A., Bolling, B., Wijaya, H. (2010). Flavonoid content and antioxidant activity of vegetables from Indonesia. Food Chemistry, 121, 1231-1235.

Apriady, R.A. (2010). Identification of phenolic acid compounds of Indonesia's indigenous vegetables. Thesis. Bogor: Faculty of Agricultural Technology in Bogor Agricultural University.

AOAC. (2005). Method of analysis, washington:assosiation of official analytical chemistry, USA : AOAC International.

Bansode, D.S., Chavan, M.D. (2012). Studies on antimicrobial activity and phytochemical analysis of citrus fruit juices against selected enteric pathogens. International Research Journal of Pharmacy, 3(11),122-126.

Brand-Williams, W., Cuvelier, M.E., Berset, C. (1995). Use of a free radical method to 
evaluate antioxidant activity. LebensmittelWissenschaft und -Technologie, 28, 25-30.

Calabro, M.L., Galtieri, V., Cutroneo, P., Tommasini, S., Ficarra, P., Ficarra, R. (2004). Study of the extraction procedure by experimental design and validation of a LC method for determination of flavonoids in Citrus bergamia juice. Journal of Pharmaceutical and Biomedical Analysis, 35, 349- 36.

Chanda, S., Dave, R. (2009). In vivo models for antioxidant activity evaluation and some medicinal plants possessing antioxidant properties: An overview. African Journal of Microbiology Research, 3(13), 981-996.

Chlopicka, J., Pasko, P., Gorinstein, S., Jedryas, A., Zagrodzki, P. (2012). Total phenolic and total flavonoid content, and antioxidant activity and sensory evaluation of pseudocereal breads, LWT Food Science Technology, 46, 548-555.

Dineshkumar, B., Analavamitra, Manjunatha, M. (2010). A comparative study of alpha amylase inhibitory activities of common antidiabetic plants of Kharagpur L block. International Journal of Green Pharmacy, 4, 115-121.

Fernandez-Lopez, J., Zhi, N., Aleson-Carbonell, L., Perez-Alvarez, J.A., Kura, V. (2005). Antioxidant and antibacterial activities of natural extracts: application in beef meatballs. Meat Science, 69, 371-380.

Firdrianny, I., Puspitasari, N., Singgih, M. (2014). Antioxidant activity, total flavonoid, phenolic, carotenoid of various shell extracts from four species of legumes. Asian Journal of Pharmaceutical and Clinical Research, 7(4), 42-46.

Fifa, T.D.B., Debiton, E., Avlessi, F., Forestier, C. (2014). In vitro biological effects of two anti-diabetic medicinal plants used in benin as folk medicine. BMC Complement Alternative Medicine, 13, 51.

Giwa, S.O., Ertunc, S., Alpbaz, M., Hapoglu, H. (2012). Electrocoagulation treatment of turbid petrochemical wastewater, International Journal of Engineering Research and Technology, 5(5), 23-91.
Hajimahmoodi, M., Aliabadipoor. M., Moghaddam, G., Sadeghi, N., Oveisi, M.R., Jannat, B. (2012). Evaluation of in vitro antioxidant activities of lemon juice for safety assessment. American Journal of Food Technology, 7(11), 708-714.

Harborne, J.B. (1996). Phytochemical Method, Padmawinata $\mathrm{K}$ and Soediro I (Eds.), Bandung : Institut Teknologi Bandung.

Hassan, H.N.A., Barsum, B.N., Habib, I.H.I. (1999). Simultaneous spectrophotometric determination of rutin, quercetin and ascorbic acid in drugs using a Kalman Filter approach. Journal of Pharmaceutical and Biomedical Analysis, 20(1-2), 315-320.

Hui, Y.H. (2010). Handbook of Fruit and Vegetable Flavors. New Jersey, Canada: A John Wiley \& Sons, Inc.

Jabłońska-Ryś, E., Zalewska-Korona, M., Kalbarczyk, J. (2009). Antioxidant capacity, ascorbic acid and phenolics content in wild edible fruits. Journal of Fruit Ornamental Plant Resaerch, 17, 115-120.

Jayaprakasha, G.K., Girennavar, B., Patil, B.S. (2008). Radical scavenging activities of rio red grape fruits and sour orange fruit extracts in different in vitro model systems. Bioresources Technology Journal, 99(10), 4484-4494.

Jokic, S., Mujic, I., Bicic-Kojic, A., Velic, D., Bilic, M., Planinic, M., Lukinac, J. (2014). Influence of extraction type on the total phenolics, total flavonoids, and total colour change of different varieties of pig extracts. Food in Health and Disease, ScientificProfessional Journal of Nutrition Dietitetics, 3(2), 90-95.

Keerthana, G., Kalaivani, M. K., Sumathy, A. (2013). In-vitro alpha amylase inhibitory and anti-oxidant activities of ethanolic leaf extract of Croton bonplandianum. Asian Journal of Pharmaceutical and Clinical Research. 6(suppl 4), 32-36.

Lawless, H.T., Heymann, H. (1999). Sensory evaluation of food: principles and practices. New York: Aspen Publisher, Inc.

Lee, S.Y., Mediani, A., Nur Ashikin, A.H., Azliana, A.B.S., Abas. F. (2014). 
Antioxidant and $\alpha$-glucoside inhibitory activities of the leaf and stem of selected traditional medicinal plants. International Food Research Journal, 21(1), 165-172.

Lim, S.M., Loh, S.P. (2016). In vitro antioxidant capacities and antidiabetic properties of phenolic extracts from selected citrus peels. International Food Research Journal, 23(1), 211-219.

Liu, S., Cui, M., Liu, Z., Song, F. (2004). Structural analysis of saponins from medicinal herbs using electrospray ionization tandem mass spectrometry. Journal of The American Society for Mass Spectrometry, 15,133-141.

Mathew, B.B., Kjatawa, S., Tiwari, A. (2012). Phytochemical analysis of citrus limonum pulp and peel. International Journal of Pharmacy and Pharmaceutical Sciences, 4(Issue 2), 269-371.

Mayur, B., Sandesh, S., Shruti, S., Yum, S.S. (2010). Antioxidant and $\alpha$-glucosidase inhibitory properties of Carpesium abrotanoides L. Journal of Medicinal Plant Research, 4(15), 1547-1553.

McDaugall, G.J., Stewart, D. (2005). The inhibitory effect of berry polyphenols on digestive enzymes. Biofactors, 23, 189-195.

Molina, E.G., Domínguez, R., Moreno, D.A., Viguera, C.G. (2010). Natural bioactive compounds of citrus lemon for food and health, Journal of Pharmaceutical and Biomedical Analysis, 5(1),327-345.

Mouly, P.P., Arzouyan, C.R., Gaydou, E.M., Estienne, J.M. (1994). Differentiation of citrus juices by factorial discriminant analysis using liquid chromatography of flavonone glycosides. Journal of Agricultural and Food Chemistry, 42, 70-79. Myung-Hee, K., Sung-Hoon, J., Hae-Dong, J., Mee Sook, L., Young-In, K. (2010). Antioxidant activity and $\alpha$-glucosidase inhibitory potential of onion (Allium cepa L.) extracts. Food Science and Biotechnology, 19, 159-64.

Nanumala, S.K., Tulasi, P., Sujitha, E. (2015). In vitro anti-diabetic activity of seed extracts of Cassia auriculata and Cassia angustifolia. European Journal of Experimental Biology, 5(5),12-17.

Odhav, B., Kandasamy, T., Khumalo, N, Baijnath, H. (2010). Screening of African traditional vegetables for their alphaamylase inhibitory effect. Journal of Medical Plants Research, 4(14), 1502-1507.

Okwu, D.E. (2008). Citrus fruits : a rich source of phytochemicals and their roles in human health. International Journal of Chemical Sciences, 6(2), 451-4571.

Omar, A.F.B., MatJafri, M.Z.B. (2009). Turbidimeter design and analysis: a review on optical fiber sensors for the measurement of water turbidity. Sensors, 9, 8311-8335.

Padayatty, S.J. (2003). Review vitamin C as an antioxidant: evaluation of its role in disease prevention. Journal of American College Nutrition, 22, 18-35.

Penniston, K.L., Nakada, S.Y., Holmes, R.P., Assimos, D.G. (2009). Quantitative assesment of citric acid in lemon juice lime juice, and commercially available fruit juice products. Journal of Endourology, 22(3), 567-570.

Porras, I., Brotons, J.M., Conesa, A., Castañer, R., Pérez-Tornero, O., Manera, F.J. (2015). Quality and fruit colour change in Verna lemon. Journal of Applied Botany Food Quality, 88, 215 - 221.

Rebaya, A., Belghith, S.I., Baghdikian, B., Ledder, V.M., Mabrouki, F., Olivier, E., Cherif, J.K., Ayadi, M.T. (2014). Total phenol, total flavonoid, tannin content, and antioxidant capacity of Halimium halimifolium (Cistaceae). Journal of Applied Pharmaceutical Science, 5(1), 052057.

Schieber, A., Stintzing, F.C., Carle, R. (2001). By products of plant food processing as a source of functional compounds - recent developments. Trends in Food Science Technology, 12, 401-413.

Siebert, K.J., Lynn, P.Y., Carrasco, A. (1996). Formation of protein - polyphenol haze in beverages. Journal of Agricultural and Food Chemistry, 44(8), 1997-2005. 
Singleton, V.L., Orthofer, R., LamuelaRaventos, R.M. (1999). Analysis of total phenols and other oxidation substrates and antioxidants by means of folin-ciocalteu reagent. Methods Enzymology, 99.152-178.

Srisook, K., Buapool, D., Boonbai, R., Simmasut, P., Charoensuk, Y., Srisook, E. (2012). Antioxidant and anti-inflammatory activities of hot water extract from Pluchea indica Less herbal tea. Journal of Medical Plants Research, 6(23), 4077-4081.

Stankovic, M.S. (2011). Total phenolic content, flavonoid concentration and antioxidant activity of Marrubium peregrinum L. extracts. Kragujevac Journal of Science, 33, 63-72.

Tapas, A., Sakarkar, D.M., Kakde, R.B. (2008). Flavonoids as Nutraceuticals : A Review. Tropical Journal of Pharmaceutical Research, 7(3), 1089-1099.

Taylor, A. (1993). Relationships between nutrition and oxidation. Journal of Americal College Nutrition, 12,138-146.

Traithip, A. (2005). Phytochemistry and antioxidant activity of Pluchea indica. Thesis. Thailand: Mahidol University.

Tyagi, Y.K., Kumar, A., Raj, H.G., Vohra, P., Gupta, G., Kumar, R., et al. (2005). Synthesis of novel amino and acetyl amino 4 - methyl coumarins and evaluation of their antioxidant activity. European Journal of Medicinal Chemistry, 40(4), 413-420.

Vandercook, C.E., Stephenson, R.G. (1966). Lemon juice composition. Idetification of he major phenolic compounds and estimation by paper chromatography. Journal of Agricultural and Food Chemistry, 14, 450454.

Widyawati, P.S., Budianta, T.D.W., Kusuma, F.A., Wijaya. E.L. (2014). Difference of solvent polarity to phytochemical content and antioxidant activity of Pluchea indica Less Leaves Extracts. International Journal of Pharmacognosy and Phytochemical Research, 6(4), 850-855.

Widyawati, P.S., Budianta, T.D.W., Utomo, A.R., Harianto, I. (2016). The physicochemical and antioxidant properties of Pluchea indica Less drink in tea bag packaging. International Journal of Food and Nutritional Sciences, 5(3),113-120.

Widyawati, P.S., Wijaya, C.H., Hardjosworo, P.S., Sajuthi, D. (2013). Volatile compounds of Pluchea indica Less and Ocimum basillicum Linn essential oil and potency as antioxidant. Hayati Journal Biosciences, 20(3), 117-126.

Yekeler, F.Z., Ozyurek, H., Tamer, C.E. (2013). A functional beverage: lemonade. International Science Index Nutrition Food Engineering, 7(7), 332-335.

Zhao, D.G., Zhou, A.Y., Du, Z., Zhang, Y., Zhang, K., Ma, Y.Y. (2015). Coumarins with $\alpha$-glucosidase and $\alpha$-amylase inhibitory activities from the flower of Edgeworthia gardneri. Journal of Fitoterapia, 107, 122127.

Zhuo, Z., Xi, W., Hu, Y., Nie, C., Zhou, Z. (2015). Antioxidant activity of citrus fruits. Food Chemistry, 196,885-896.

\section{Acknowledgment}

The authors would like to thank the Directorate General Higher Education (DIKTI) of the Indonesian's Government for the financial support (The competitive research grant) and Widya Mandala Catholic University in Surabaya for this research. 